ISSN electrónico: 1885-5210

DOI: https://doi.org/10.14201/rmc202016e429433

\title{
UNA NOCHE EN EL MALBRÁN
}

\section{One Night in the Malbran}

\author{
Rubén MAYER \\ Corporación Médica San Martín. Buenos Aires (Argentina). \\ Correo electrónico: mayerr@intramed.net
}

Fecha de recepción: 29 de mayo de 2020

Fecha de aceptación: 13 de junio de 2020

Fecha de publicación: 29 de enero de 2021

Son poco más de las siete de la tarde cuando el guardia de seguridad ha conseguido finalmente cerrar el pesado portón de hierro de la entrada al edificio dejando atrás otro día de trabajo frenético en el Instituto de Microbiología. Ya todos los científicos se han ido y con ellos sus incertidumbres y la insistente falta de respuestas.

Entrado el otoño y con la caída del atardecer las primeras sombras han cubierto ya las casas y los primeros pisos de los edificios que rodean al viejo predio del Instituto. En las calles vecinas apenas unos pocos apuran sus pasos pateando las hojas que el viento ha mandado a rodar por las veredas. Sólo de tanto en tanto se siente vibrar el asfalto por el paso de los últimos camiones que regresan en dirección al sur, a los suburbios.

En el interior del laboratorio principal la oscuridad aún no es completa porque desde la lámpara que se encuentra en el hall de entrada llega una penumbra que delicadamente ilumina un retrato de Carlos Malbrán que cuelga de una de las paredes laterales. Al detenerse en su rostro, la luz parece traer al presente su expresión atenta e interesada, como si estuviera observando ahora mismo lo que allí está pasando.

Por lo demás, y como siempre al final de cada jornada, en el interior del laboratorio todo es silencio. Sin embargo, en esta oscura noche de otoño en Buenos Aires, un murmullo apenas perceptible parece venir de la mesa donde, en línea, se encuentran uno a continuación del otro los microscopios.

- Hey. Pssst! Hey!!!

- ¿A mí?

- Sí, a usted, el que está en el preparado del microscopio de al lado. 
- ¿Nos conocemos?

- No, pero llevamos unos días los dos acá y me pareció que ya era momento de presentarme. Soy Flavivirus pero puede decirme Dengue, que está mejor y es como todos me conocen acá.

- Un gusto. Yo soy el SARS-CoV-2 o simplemente Coronavirus, o si usted prefiere COVID-19.

- Sí, claro, y yo soy la reina de Inglaterra.

- Pero ¿por qué habría de mentirle?, ¿qué necesidad tengo? Acérquese un poco y míreme bien. ¿Ve que no le miento?

- Tiene razón, discúlpeme. Es que hace tiempo que por acá no vemos ninguna cara nueva. COVID-19...quién lo hubiera dicho! Cuando les cuente a los de mi género no me lo van a creer. ¿No da para una selfie, no?

COVID-19 no se esforzó en ocultar una mueca de fastidio e hizo como que no lo había escuchado retomando allí donde la conversación los había dejado.

- Cuénteme mejor un poco de usted, en qué anda, su familia...

- Hasta lo que pude rastrear, mis antepasados más lejanos eran de África, por eso si a mí me dan a elegir prefiero mil veces el calor. Estamos hablando de siglos, pero acá en Sudamérica llevamos apenas 40 años. Al principio fuimos llegando con los barcos, que era la manera como se viajaba y se comercializaba por aquel entonces, a muchos nos gustó el lugar y decidimos quedarnos.

- A mí al revés, a mí deme el frío. La temporada alta para nosotros empezó hace pocos meses, en China, en diciembre pasado, pero a nosotros la globalización y el turismo sin freno nos dio una movilidad que no imaginábamos ni en los cálculos más optimistas. Estamos recorriendo el mundo, vea. La gente por estos días trabaja demasiado, se aburre con facilidad y pareciera que viajar por el mundo le devuelve algún sentido a su esfuerzo.

Habrá oído hablar del mercado de Wuhan, supongo.
- No se habla de otra cosa por estos días. Usted, además, creo que está al tanto de que se ha hecho famoso, todo un rock star.

- ¿Un qué?

- Olvídelo, no tiene importancia. A propósito, ¿qué hay de cierto de ese asunto de los murciélagos? Se dice que por sus pagos no le hacen asco a nada, que todo bicho que camina va a parar al asador. También se comenta que a usted y a los suyos los hicieron en un laboratorio por encargo.

- ¿Quiere que le diga la verdad? No sé. Se están diciendo demasiadas cosas que nada que ver. Para mí se están haciendo los distraídos para no hacerse cargo de las macanas que vienen haciendo no de ayer ni de antes de ayer sino de mucho tiempo atrás.

- Coincido. Ahora ponen cara de yo no fui, como perro que volteó la olla. Tarde además porque, como se dice en estos casos, de nada sirve llorar sobre la leche derramada. ¿Me sigue?

A COVID-19 se le escapaban por desconocidas algunas expresiones populares y trataba de disimular como podía su condición de recién llegado a estas geografías. Dengue, en cambio, ya se había empapado de la cultura, de algunos gestos y modismos autóctonos. Ya estaba canchero, por decirlo de alguna manera.

- A mí de usted me han contado que no anda solo, que se hace llevar por un mosquito. ¿Es así como dicen?

- Tal cual, el Aedes aegypti. A la hora de ponerles nombres a los bichos los científicos no reparan en gastos. El mosquito es para nosotros lo que la vinchuca al Trypanosoma cruzi, un caballo de Troya. Tenemos tercerizado el acarreo, por supuesto como personal contratado porque ponerlo en blanco es una bocha de guita.

- Bocha de guita...me está gustando el lunfardo ¿sabe? Yo lo veo como una forma de poesía rea que gusta de jugar con las palabras buscando combinaciones curiosas con esa fantasía irrespetuosa tan de los niños. 
A mitad de la madrugada ya todo está en calma, "el músculo duerme, la ambición descansa", como reza el tango. Nada o casi nada queda del olor persistente de las sustancias químicas que allí se usan. Ni de las agitadas discusiones de los científicos, de las preguntas que entre ellos se hacían o las que ellos se hacían a sí mismos, mascullando impotencia.

Sólo se escucha a cada tanto el ladrido de unos perros callejeros o el crujir de único viejo mueble de madera que allí han dejado. Una gota de agua asoma en una de las canillas, se aferra al pico, resiste, pero finalmente cae lentamente como si fuera una baba pegajosa.

- Para mi sorpresa del que se ha vuelto hablar por estos días es del Morbillivirus. Yo creía que el sarampión ya era historia pasada.

- Era, pero le perdonaron la vida, lo dejaron en partido como dicen los periodistas deportivos. $Y$ usted ya sabe: el que se va sin que lo echen...

COVID-19 recogió el guante y se animó a tararear un tango:

- "Volvió una noche, no la esperaban..."

Dengue lo miró sorprendido y hasta se le escapó una sonrisa cómplice de aprobación.

- Es que si bien hace pocos meses que ando por acá algunas cositas se me van pegando. Lo que no termino de entender es a esta gente, puntualmente eso del homo sapiens.

- Quédese tranquilo que no es el único que no lo entiende. Hacen y deshacen sin medir en las consecuencias y como si fuera poco se confían. Parece que nunca aprenden que nosotros los virus nunca nos vamos. Los virus, COVID-19 querido, son como el sol, que aunque no los veamos siempre están.

- Si me permite, le confieso que a nosotros en Oriente nos causa un poco de gracia esos que ustedes consideran los líderes de Occidente -al pronunciar "líderes", COVID-19 usó un tono levemente irónico e hizo un movimiento con dos de sus prolongaciones como quien pone una palabra entre comillas- muchos de ellos claramente no están a la altura, cada uno hace la suya y para peor los países más ricos no se comprometen para ayudar a los más pobres...

- Con todo respeto COVID-19, pero ahí se le escapó un lagrimón de nostalgia comunista.

- Bueno, no se olvide de mis orígenes: donde hubo Mao, Xi Jinping queda.

Por la avenida pasaron un par de ambulancias haciendo sonar sus sirenas pero la conversación, lejos de interrumpirse por el estruendo, fluía con la sorprendente naturalidad que a veces se da entre dos desconocidos.

- Escuche lo que repite esta gente por estos días, escuche y piénselo bien antes de sacar conclusiones: "las crisis son oportunidades".

- Como idea es interesante. Para nosotros los virus una crisis es el momento echar mano a una mutación. Casi nunca falla.

- Oiga esta otra: "cocodrilo que se duerme es cartera". No me mire así, se la escuché decir a la secretaria del jefe. "Siempre que llovió, paró" es otra que ya la escuché varias veces. Esta gente siempre tiene a mano un repertorio de frases hechas y lugares comunes para adaptarse a las circunstancias y patear los problemas para adelante. En fin.

A medida que hablaban se iban soltando, dándole a la conversación la confianza y la calidez necesarias para cambiar distancia por intimidad. Empezaron a compartir vivencias personales, sensaciones, como cuando virus y médico a uno y otro extremo del microscopio se observaban: el hombre tratando de entender y el virus aprendiendo a discernir por la apariencia del ojo la mirada torva del escéptico de la mirada de asombro del novato, la mirada encendida del enamorado de la mirada gris de los solitarios, las diferentes miradas deseantes del hombre y de la mujer.

- Cambiando de tema, ¿sabe cómo nos andan diciendo los médicos a usted y a mí?: Covadengue, porque la mayoría de las veces buscándolo a usted me encuentran a mí. 
- Esto de Covadengue me trae a la memoria el concepto de Binomio Fantástico que dijo un italiano que si mal no recuerdo se llama, o se llamaba, Gianni Rodari. La cosa funciona así: dele a la imaginación dos palabras lo suficientemente extrañas la una de la otra, como usted y como yo por caso, que ella, la imaginación, se va a encargar de encontrarles un parentesco y una convivencia posible.

- Se ve que a pesar de todo usted se da tiempo para la lectura culta.

- Sin exagerar, pero para quien tiene ganas y voluntad siempre es posible hacerse de un poco de tiempo durante el período de incubación. Después ya no, después el trabajo es fultaim. Disculpe si no lo pronuncié bien, sepa entender que el inglés no es lo mío. Ando poco por aquellas latitudes.

- Está disculpado, bastante bien igual. Ya que estamos en el tema de los dimes y diretes, le comento que a mí me llegó que a nosotros los coronavirus la gente no nos puede ni ver.

- Ah, se hace el gracioso. Y a mí que usted se hizo viral.

- Usted no se queda atrás, eh. Se comió un payaso parece. Está muy bien, no están los tiempos como para despreciar el chiste fácil. Sin humor, estimado Dengue, qué nos queda.

- Bueno COVID-19, lo voy a tener que dejar, todavía tengo para unos días. El mío es un trabajo golondrina. De verdad le digo, fue un gusto conversar con usted. Me habían llegado versiones de que era mal bicho, pero nada que ver. ¿Usted se queda?
- Sí, yo tengo para rato. Lo mío, como me ha explicado usted que dicen los amantes del fútbol, es un partido largo de 180 minutos.

Empieza a clarear en la ciudad. Sobre la larga mesada que da sobre el ventanal los primeros brillos de la mañana van contorneando uno a uno los perfiles de gran cantidad de frascos de vidrio allí apoyados, creando formas variadas y extrañas en un conjunto de apariencia curiosa, casi artística.

Tímidamente empiezan a circular algunos autos en dirección al centro y las pocas personas que surcan las veredas caminan inseguras, como midiendo la distancia que las separa a medida que se van acercando. Todas tienen tapadas su nariz y sus bocas y de sus rostros sólo quedan a la intemperie sus ojos y una mirada que se esfuerza inútilmente en atrapar una realidad que se le presenta insólita. Parecen criaturas frágiles y asustadizas, como esos niños que se han extraviado y que esperan ser reencontrados y devueltos a un mundo que conocían y que les fue repentinamente sustraído.

Faltan pocos minutos para las seis y el primero en llegar al Instituto de Microbiología es el recambio de la guardia de seguridad. El saliente bosteza y habla al mismo tiempo por lo que apenas si se entiende lo que dice. Parece apurado por lo que el saludo se limita a unas pocas palabras en un diálogo breve y previsible:

- ¿Cómo estuvo?, ¿novedades?

- Lo de siempre. Gatos desesperados por encontrar algo para comer y un lugar donde protegerse del frío de la noche.

Adentro del laboratorio, nada del otro mundo, todo tranquilo. 


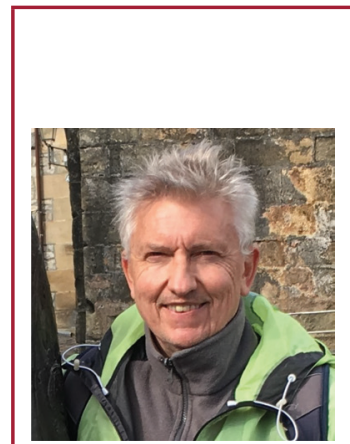

Rubén Mayer. 1981: Título de Médico otorgado por la Facultad de Medicina de la UBA (Universidad de Buenos Aires). 1984-1989: Residencia y Jefatura de Residentes, Sanatorio Güemes/Fundación Favaloro (Buenos Aires). 1989: título de Especialista en Cardiología otorgado por el Ministerio de Salud de la Nación. 1995-2001: Sala de Internados del Servicio de Cardiología del Hospital Cosme Argerich (Buenos Aires). 2004-2012: Consultorios Externos del Instituto de Cardiología y Cirugía Cardiovascular de la Fundación Favaloro (Buenos Aires). Actualmente y desde 1995: Consultorios Externos de la Corporación Médica San Martín (Buenos Aires). Desde 2013: Sala de internados del departamento de Cardiología del Hospital Universitario de la Universidad Interamericana (UAI), actualmente Sanatorio Santa Bárbara (Buenos Aires). Docente de la Carrera de Especialista en Cardiología y de la Maestría en Síndromes Coronarios Agudos de la UAl. 